\title{
PERAN KESBANGPOL LINMAS DALAM PEMBINAAN ORGANISASI SOSIAL POLITIK DAN ORGANISASI KEMASYARAKATAN
}

\author{
Yasni Efyanti \\ Institut Agama Islam Negeri (LAIN) Kerinci \\ email: yasniefyanti@iainkerinci.ac.id
}

\begin{abstract}
Development in the socio-political field and stabilization of political awareness of life are necessary for every citizen, in order to achieve Pancasila Democracy so that it can guarantee the smooth running of the business to achieve the national goals. This research uses a practical juridical approach. The data obtained will then be analyzed qualitatively by drawing conclusions using inductive methods. The results of this study include: 1) the efforts made by KESBANGPOL LINMAS Sungai Penuh City to maintain political stability in the field of social politics is to provide guidance to existing community organizations, such training is carried out through training in the field of political social. Whereas for social and political power organizations, guidance in the implementation of elections is conducted by conducting scale meetings twice a year to administrators of social political organizations, helping to solve problems faced by these organizations in facing general elections and helping to bold operational facilities.
\end{abstract}

Keywords: Kesbangol Linmas, Social Political Organizations, Community Organizations

\begin{abstract}
Abstrak: Pembangunan dalam bidang sosial politik dan pemantapan akan kesadaran kehidupan berpolitik perlu bagi setiap warga, demi tercapainya Demokrasi Pancasila sehingga dapat menjamin kelancaran usaha untuk mencapai tujuaan nasional. Penelitian ini menggunakan pendekatan yuridis praktis. Data yang diperoleh nantinya akan dianalisis secara kualitatif yaitu dengan menarik kesimpulan menggunakan metode induktif. Hasil penelitian ini antara lain: 1) usaha-usaha yang dilakukan oleh KESBANGPOL LINMAS Kota Sungai Penuh untuk menjaga kestabilan politik dibidang social politik adalah dengan melakukan pembinaan terhadap organisasi kemasyarakatan yang ada, pembinaan tersebut dilakukan lewat pelatihan-pelatihan dibidang social politik. Sedangkan terhadap organisasi kekuatan social politik dilakukan pembinaan dibidang penyelenggaraan dalam pelaksanaan pemilihan umum dengan cara melakukan pertemuan berskala dua kali setahun kepada pengurus organisasi social politik,membantu memecahkan persoalan yang dihadapi organisasi tersebut dalam menghadapi pemilihan umumdan membantu mengadakan fasilitas operasional.
\end{abstract}

Kata Kunci: Kesbangol Linmas, Organisasi Sosial Politik, Organisasi Kemasyarakatan 


\section{PENDAHULUAN}

Pada hakekatnya pembangunan nasional adalah pembangunan manusia Indonesia seutuhnya dan pembangunan seluruh masyarakat Indonesia. Landasan pelaksanaan disegala bidang tersebut adalah Pancasila dan Undang- Undang Dasar 1945. Pembangunan sosial politik merupakan salah satu aspek pembangunan nasional yang biasa dipandang sebagai wahana bagi aspek pembangunan lainnya. Untuk negara yang sedang berkembang, pembangunan social politik bertujuan mempertinggi kemampuan dari wadah sistim politik.

Dalam hubungannya dengan proses modernisasi sistim politik itu terutama ditentukan oleh efektifitasnya dalam menciptakan kondisi yang dapat menyentuh harapan serta keinginan para warga untuk maju dan berkembang, sebab apabila sekedar keinginan sekelompok masyarakat tidaklah mungkin dapat membawa kedalam proses modernisasi dalam arti kata yang sebenarnya.

Dalam kaitannya dengan pembangunan dibidang politik Alpian dan Nazaruddin Syamsuddin mengatakan: "Pembangunan politik yang dikaitkan dengan hal-hal yang mungkin akan terjadi dimasa depan dan memang patut mendapat perhatian kita karena masyarakat itu kita ketahui terus menerus mengalami perubahan, apabila pada masa-masa akhir-akhir ini perubahan berlangsung sedemikian cepatnya sehingga lahir ucapan seperti "Multipe revolution in one generation", "The past and the future overlap" dan sebagainya. Mengingat hal itu, memang kondisi kemasyarakatan pada masa kini, antara lain masyarakat yang semakin maju, sehingga hasil komulatif dari berbagai factor perubahan social-perubahan social baik yang bersifat global, regional maupun rasional, pembangunan politik kita lakukan dimasa depan wajib mengantisipasikan berbagai perkembangan yang mungkin akan terjadi dimasa depan itu."

Pembangunan dalam bidang sscial politik dan pemantapan akan kesadaran kehidupan berpolitik perlu bagi setiap warga, demi tercapainya Demokrasi Pancasila sehingga dapat menjamin kelancaran usaha untuk mencapai tujuaan nasional. Landasan hukum untuk tumbuh dan berkembangnya kehidupan berpolitik di Indonesia adalah sebagaimana yang ditentukan dalam Pasal 28 Undang-Undang Dasar 1945 yakni "Kemerdekaan berserikat dan berkumpul, mengeluarkan pendapat baik secara lisan maupun dengan tulisan dan sebagainya ditetapkan oleh Undang-Undang."

Dari ketentuan Pasal 28 ini dapatlah diketahui bahwa setiap warga negara Indonesia punya kebebasan untuk mengeluarkan pendapat baik secara lisan maupun tulisan. Untuk tercapainya stabilitas dan kemantapan di bidang sosial dan politik haruslah diusahakan 
kokohnya persatuan dan kesatuan bangsa. Semakin kokohnya kehidupan yang konstitusional, demokrasi dan berdasarkan hukum dalam mengayomi masyarakat yang merupakan syarat bagi tercapainya stabilitas yang mantap.

Usaha-usaha untuk meningkatkan pembangunan di bidang sosial dan politik, aparatur pemerintah harus mendorong masyarakat untuk mengembangkan kreatifitas masyarakat, kegairahan hidup dan memperluas partisipasi masyarakat dalam pelaksanaan pembangunan. Pemerintah berkewajiban memberikan pengarahan dan bimbingan terhadap pertumbuhan kehidupan sosial politik serta menciptakan iklim yang sehat bagi pertumbuhannya. Dilain pihak masyarakat diharapkan juga memberikan tanggapan terhadap pengarahan dan bimbingan yang diberikan oleh aparatur pemerintah serta menciptakan iklim tersebut dengan kegiatan yang nyata seperti turut serta dalam suatu organisasi social politik dan organisasi kemasyarakatan yang ada sehingga dengan demikian terciptalah komunikasi social timbal balik antara masyarakat dengan masyarakat, antara masyarakat dengan pemerintah.

Dalam penyelenggaraan urusan pemerintahan di bidang Kesatuan Bangsa dan Politik dan LINMAS, Walikota Kota Sungai Penuh dibantu oleh Kantor KESBANGPOLLINMAS Kota Sungai Penuh sebagai pendukung tugas kepala daerah dalam menyelenggarakan pemerintahan di bidang Kesatuan Bangsa dan Politik.

KESBANGPOL-LINMAS Kota Sungai Penuh, merupakan SKPD (Satuan Kerja Perangkat Daerah) dibentuk berdasarkan Peraturan Daerah Kota Sungai Penuh Nomor 22 Tahun 2010 Tentang Organisasi dan Tata Kerja Inspektorat, Bapeda, dan Lembaga Teknis Daerah Kota Sungai Penuh, dan agar Kantor Kesatuan Bangsa dan Politik Kota Sungai Penuh bisa berdaya guna dan berhasil guna, Walikota Sungai Penuh menetapkan Peraturan Walikota Sungai Penuh Nomor 80 Tahun 2010 Tentang Uraian Tugas Pokok, Fungsi dan Tata Kerja Kantor KESBANGPOL-LINMAS Kota Sungai Penuh

Adapun yang menjadi tugas Kantor Kesatuan Bangsa dan Politik Kota Sungai Penuh berdasarkan Peraturan Walikota Sungai Penuh Nomor 80 Tahun 2010 adalah: Melaksanakan penyusunan dan pelaksanaan kebijakan dibidang Kesatuan Bangsa dan Politik. Untuk melaksanakan tugas pokok diatas, Kantor Kesatuan Bangsa dan Politik Kota Sungai Penuh menyelenggarakan fungsi: 1) perumusan kebijakan teknis Kesatuan Bangsa dan Politik; 2)pemberian dukungan atas penyelenggaraan pemerintahan daerah dibidang Kesatuan Bangsa dan Politik, pengawasan penyelenggaraan pemerintahan dibidang Kesatuan Bangsa dan Politik; 3) pembinaan dan pelaksanaan tugas Kesatuan Bangsa dan Politik; 4) pengawasan penyelenggaraan pemerintahan dibidang Kesatuan Bangsa dan Politik; dan 5) pelaksanaan tugas lain yang diberikan oleh Walikota sesuai dengan tugas dan fungsinya. 
Dari hal tersebut diatas terlihat betapa beratnya tugas yang diemban oleh Kantor kesatuan Bangsa dan Politik. Apalagi saat ini organisasi social politik dan organisasi kemasyarakatan yang berfungsi sebagai sarana untuk menyalurkan pendapat dan pikiran bagi anggota masyarakat Warganegara Republik Indonesia terus tumbuh dan berkembang.

Organisasi kemasyarakatan dan Lembaga Swadaya Masyarakat (LSM) sangat berperan dalam pembangunan demokrasi di Indonesia. Organisasi kemasyarakatan dan Lembaga Swadaya Masyarakat merupakan organisasi masyarakat yang berada di tengah masyarakat yang menjalankan fungsi pengawasan kepada pemerintah. Disinilah letak pentingnya peranan Kantor KESBANGPOL-LINMAS dalam melakukan pembinaan terhadap organisasi kemasyarakatan dan Lembaga Swadaya Masyarakat.

Proses pembinaan social politik dan organisasi kemasyarakatan bertujuan untuk mengatasi konflik yang mungkin timbul akibat banyaknya partai politik dan organisasi kemasyarakatan yang ada. Sebagaimana diketahui selain diberikannya kemerdekaan berserikat dan berkumpul, seperti yang tertuang di dalam Pasal 28 Undang Undang Dasar 1945 juga terdapat batasan-batasan yang tidak boleh dilanggar. Organisasi Kemasyarakatan yang ada merupakan kumpulan dari masyarakat yang mana masing-masing mewakili berbagai kelompok dan aliran yang hidup dalam masyarakat yang masing-masing mempunyai aspirasi dan keinginan-keinginan tertentu. Masalahnya sekarang adalah bagaimana mengusahakan agar tingkah laku politik masyarakat bisa sesuai dengan demokrasi Pancasila.

Berdasarkan pengamatan yang penulis lakukan di KESBANGPOL- LINMAS Kota Sungai Penuh, pembinaan sosial politik dilakukan terhadap organisasi kekuatan sosial politik dan organisasi kemasyarakatan yang ada. Namun dalam pelaksanaannya masih ditemui masalah yaitu masih adanya organisasi kemasyarakatan yang tidak terdaftar dan kurangnya pemahaman terhadap maksud dan tujuan dari pelaksanaan pembinaan tersebut.

Melihat banyaknya Organisasi Kemasyarakatan dan sosial politik yang ada dalam lingkungan Kota Sungai Penuh, menjadi sangat penting untuk menanamkan kesadaran yang seimbang dalam diri masyarakat sebagaimana yang dituntut oleh sistim Demokrasi Pancasila dan bagaimana menciptakan suatu mekanisme politik yang dapat menjaga kestabilan politik, maka penulis ingin melihat bagaimana Peran KESBANGPOL-LINMAS Kota Sungai Penuh dalam melaksanakan pembinaan terhadap Organisasi Kemasyarakatan yang ada di lingkungan Kota Sungai Penuh. Tujuan dalam penelitian ini adalah : 1) untuk mengetahui peran KESBANGPOL LINMAS dalam melaksanakan pembinaan terhadap organisasi kemasyarakatan; 2) untuk mengetahui kendala-kendala yang dihadapi dalam pelaksanaan pembinaan terhadap organisasi kemasyarakatan dan upaya penanggulangannya. 


\section{METODE}

Dalam penelitian ini menggunakan pendekatan yuridis praktis. Di mana penelitian dilakukan untuk melihat sejauh mana ketentuan dan perundang-undangan yang ada dihubungkan dengan prakteknya tentang peran Kesbangpol Linmas dalam melaksanakan pembinaan terhadap organisasi kemasyarakatan. Data yang diperoleh secara langsung dari lapangan yakni data primer dikumpulkan kemudian diklasifikasikam ke dalam bentuk table. Data yang diperoleh nantinya akan dianalisis secara kualitatif yaitu dengan menarik kesimpulan menggunakan metode induktif. Hasil yang diperoleh disajikan ke dalam bentuk deskriptif yaitu dengan menggambarkan kenyataan yang terjadi di lapangan tentang pelaksanaan pembinaan oleh Kesbangpol Linmas terhadap organisasi kemasyarakatan yang ada di lingkungan Kota Sungai Penuh.

\section{HASIL PENELITIAN DAN PEMBAHASAN}

\section{Peran KESBANGPOL dalam Melaksanakan Pembinaan Terhadap Organisasi Sosial Politik}

Dalam kehidupan politik kekuasaan tidak hanya didudukkan sebagai objek dan tujuan, tetapi hendaknya dipahami sebagai alat untuk mensejahterakan seluruh rakyat. Untuk itu diperlukan adanya keterkaitan interdependensi antara struktur-struktur yang bernaung di bawah sistem kekuasaan tersebut. Hal ini dimaksudkan agar harmonisasi interaktif dalam kehidupan politik dapat terselenggara. Bila pemikiran tersebut dapat diterima dan digunakan untuk memahami kerangka suatu sistem politik, maka interdependensi tersebut hanya dapat diterjemahkan dalam suasana pemerintahan yang demokratis. Dalam sistem yang demokratis interdependensi dapat berarti adanya kemandirian organisasi sosial politik sebagai infrastruktur politik untuk berpartisipasi aktif dalam proses pengambilan keputusan, baik berupa kebijakan maupun peraturan perundang- undangan. Dengan kemandirian itu diharapkan organisasi sosial politik dapat berperan sebagai subjek, sedangkan tujuan itu sendiri sebagai objek yang dirumuskan dan diputuskan berdasar kesepakatan bersama. Atas dasar pemikiran ini maka dirasa perlu untuk melakukan pembinaan kepada organisasi sosial dan politik.

Sebagaimana dijelaskan pada $\mathrm{BAB}$ sebelumnya bahwa pembinaan yang dilakukan oleh KESBANGPOL Kota Sungai Penuh meliputi pembinaan umum dan kemasyarakatan, pembinaan politik dan kesatuan bangsa, kewaspadaan dan konflik penanganan politik.

Pembinaan social politik sangat penting untuk dilaksanakan, disamping untuk 
menutup peluang terjadinya konflik di bidang social politik, juga dapat dibayangkan bagaimana sulitnya memelihara dan menjaga stabilitas nasional yang sehat dan dinamis. Bila pembinaan terhadap organisasi social politik dan organisasi kemasyarakatan yang ada tidak dilaksanakan.

Pembinaan yang dilakukan berdasarkan pada dugaan bahwa akan timbul banyak masalah jika tidak adanya pembinaan, misalnya terjadinya bentrokan kepentingan antara organisasi yang satu dengan organisasi yang lain. Hal ini tidak sesuai dengan system politik di masa mendatang yang menginginkan operasionalisasi system politik demokrasi pancasila yang semakin dekat dengan kehidupan masyarakat, yang lebih bersifat mendidik, dan yang peka terhadap masalah-masalah masyarakat dan mampu mengaktualisasikan aspirasi masyarakat dan yang menuntut kehidupan nasional yang semakin berkualitas.

Sehubungan dengan hal tersebut diatas, perlu kiranya penulis sajikan gambaran upaya pembinaan yang dilakukan oleh KESBANGPOL Kota Sungai Penuh yaitu :

Dalam hal pembinaan

a. Mendorong organisasi meningkatkan wawasan

b. Meningkatkan pemahaman dibidang pengelolaan kehidupan organisasi

c. Membimbing organisasi menetapkan programnya

d. Menumbuhkembangkan kepekaan anggota organisasi sebagai wadah penampung aspirasi masyarakat

e. Memberikan perlindungan hak

f. Menempatkan organisasi berdasarkan prinsip legalitas, konstitusional

g. Menilai kegiatan organisasi.

Dalam hal meningkatkan kemandirian

a. Penataan organisasi

b. Menciptakan disiplin anggota

c. Mempertebal rasa persatuan dan kesatuan

d. Menumbuhkan rasa tanggung jawab pada anggota

e. Mendorong terciptanya kesadaran pengurus menyangkut pentingnya peran organisasi

f. Mengarahkan agar pengurus dan anggota mampu melaksanakan fungsi, hak dan kewajibannya

g. Mengelola kehidupan organisasi berdasarkan peraturan intern organisasi

h. Melepaskan organisasi dari ketergantungan pada pemerintah. 
Meningkatkan kemampuan

a. Mengarahkan program organisasi dilaksanakan dalam karya nyata

b. Mendorong organisasi melakukan pendaftaran anggota

c. Membimbing organisasi mentaati AD/ART

d. Membimbing agar keberadaannya dapat dirasakan manfaatnya

e. Meningkatkan kesadaran anggota tentang hak dan kewajibannya sebagai warga negara.

f. Mengarahkan agar organisasi dapat menyelesaikan masalah internal organisasi.

g. Mengarahkan organisasi tidak tergantung kepada pihak lain.

Upaya-upaya yang ditempuh tersebut, dilaksanakan lewat pelatihan- pelatihan bidang pembinaan social politik yang dapat dilihat pada table berikut :

Tabel 1 . Pembinaan yang Dilakukan oleh Kesbangpol Kota Sungai Penuh Pada Tahun 2018

\begin{tabular}{clc}
\hline No & \multicolumn{1}{c}{ Pembinaan yang dilakukan } & Jumlah \\
\hline 1 & Pekan Komunikasi dan Konsultasi social politik bagi anggota Ormas. & 1 \\
& Sosialisasi Undang-Undang Nomor 16 Tahun 2017 Tentang Penetapan & \multirow{2}{*}{$\begin{array}{l}\text { PP Pengganti Undang-Undang Nomor 17 Tahun 2013 Tentang } \\
\text { Organisasi Kemasyarakatan }\end{array}$} \\
\hline
\end{tabular}

Berdasarkan pada table 1 terlihat bahwa pada tahun anggaran 2018 hanya dilakukan pembinaan social politik sebanyak 2 kali, hal ini karna dalam melakukan pembinaan KESBANGPOL Kota Sungai Penuh tidak memiliki program kerja yang harus diikuti. Jadi tergantung pada hal-hal yang dipandang perlu untuk dilaksanakan atau situasi yang berkembang di masyarakat.Akibat dari hal tersebut, dalam kenyataannya terdapat organisasi yang sudah dibina beberapa kali dan ada juga organisasi yang belum dibina sama sekali. Hal ini sesuai dengan data yang penulis perolah di lapangan, dimana dari 25 responden, 3 organisasi kemasyarakatan telah dibina dua kali, 16 organisasi kemasyarakatan dibina satu kali dan 6 organisasi kemasyarakatan belum dibina sama sekali.

Pembinaan yang dilakukan bersifat umum dimana KESBANGPOL Kota Sungai Penuh mengadakan koordinasi dengan instansi terkait sebagai Pembina teknis. Adapun dalam satu tahun KESBANGPOL Kota Sungai Penuh hanya dapat membina paling banyak $15 \%$ dari jumlah organisasi kemasyarakatan yang ada. Berikut gambaran jumlah organisasi kemasyarakatan yang ada dan organisasi kemasyarakatan yang bisa dibina dalam satu tahun. 
Tabel II. Jumlah Organisasi Kemasyarakatan yang Terdaftar di Kesbangpol Linmas Kota Sungai Penuh sampai Tahun 2018

\begin{tabular}{clc}
\hline No & \multicolumn{1}{c}{ Jenis Organisasi } & Jumlah Organisasi \\
\hline 1 & Kategori Organisasi Berbasis Massa & 27 \\
2 & Kategori Organisasi Tidak Berbasis Massa & 33 \\
\hline & Jumlah & 60 \\
\hline
\end{tabular}

Sumber : Data Kesbangpol Kota Sungai Penuh

Berdasarkan tabel II tergambar jumlah organisasi kemasyarakatan yang ada di Kota Sungai Penuh sampai dengan tahun anggaran 2018 terdapat 60 Organisasi, dari 60 organisasi yang terdaftar yang dapat dibina berjumlah 19 Organisasi. Untuk jelasnya dapat dilihat pada tabel di bawah ini :

Tabel III. Jumlah Organisasi Kemasyarakatan Yang Dibina pada Tahun Anggaran 2018

\begin{tabular}{llc}
\hline No & \multicolumn{1}{c}{ Jenis Organisasi } & Jumlah \\
\hline 1 & Organisasi Berbasis Massa Organisasi & 10 \\
2 & Tidak Berbasisi Massa & 9 \\
\hline & JUMLAH & 19 \\
\hline
\end{tabular}

Dari tabel III ini terlihat sedikit sekali organisasi kemasyarakatan yang bisa dibina dalam kurun waktu satu tahun, hal ini menurut Bapak Desveva Endri disebabkan oleh :

1. Karena adanya AD/ART organisasi tersebut pada setiap tahun anggaran terjadi regenerasi/MUSDA

2. Karena adanya keterbatasan anggaran pada KESBANGPOL Kota Sungai Penuh

3. Tidak semua organisasi kemasyarakatan didirikan pada waktu yang sama sehingga dalam pembinaan harus mengikuti pergantian pengurus.

4. Pembinaan social politik juga tergantung pada keadaan atau situasi yang sedang berkembang.

Pembinaan social politik dilakukan oleh KESBANGPOL Kota Sungai Penuh dilakukan karena adanya kekhawatiran terhadap organisasi kemasyarakatan dan organisasi social politik selaku pelaku yang berperan dalam kehidupan social politik melakukan tindakan yang tidak sesuai dengan demokrasi pancasila.Tindakan pembinaan ini merupakan suatu tindakan pendahuluan yang dapat mencegah perkembangan kehidupan social politik kearah yang tidak diinginkan.

Mengingat banyak ragamnya organisasi kemasyarakatan yang tumbuh di masyarakat, dipandang perlu diadakan penataan kehidupan organisasi kemasyarakatan. Karena telah 
menjadi tekad dan kesepakatan bahwa kehidupan bermasyarakat, berbangsa dan bernegara ditata dan dibangun berdasarkan kepada satu ideology nasional yaitu Pancasila.

Untuk mewujudkan hal ini, langkah dan upaya yang dilakukan Kepala Kantor Kesatuan Bangsa dan Politik Kota Sungai Penuh antara lain :

1. Dalam rangka tertib administrasi Kepala Kantor Kesatuan Bangsa dan Politik Kota Sungai Penuh mengeluarkan himbauan pendaftaran organisasi kemasyarakatan/LSM/Yayasan yang ada di lingkungan Kota Sungai Penuh.

2 Guna untuk mengikuti perkembangan kondisi organisasi kemasyarakatan serta menampung aspirasimya, dilakukan rapat kerja periodic Kantor Kesatuan Bangsa dan Politik Kota Sungai Penuh dengan organisasi kemasyarakatan/LSM.

3. Dalam rangka menyikapi situasi yang sedang berkembang dan memberikan infomasi yang actual kepada organisasi kemasyarakatan/ LSM, telah dilaksanakan :

a. Audiensi atas permintaan organisasi kemasyarakatan / LSM, selama tahun 2018 telah dilakukan sebanyak 1 kali.

b. Dialog/tatap muka dengan organisasi kepemudaan dan tokoh masyarakat dan tokoh agama

c. Kunjungan silaturahmi.

4. Untuk memotifasi / mendorong organisasi kemasyarakatan/LSM/Yayasan guna melaksanakan kegiatan intern maupun ikut berpartisipasi dalam pembangunan di daerah, Walikota Sungai Penuh berkesempatan hadir memberikan sambutan/pengarahan dan membuka secara resmi setiap kegiatan MUSDA/Konferensi, RaKer maupun Pelatihan/seminar yang diadakan oleh organisasi kemasyarakatan/LSM.

5. Dalam rangka membantu kelancaran atau kehidupan organisasi maupun kegiatan yang diadakan, Walikota Sungai Penuh membantu :

a. Pendanaan baik rutin maupun insedentil sesuai kemampuan keuangan daerah.

b. Memberikan rekomendasi pelaksanaan kegiatan, memonitor dan koordinasi serta keamanan seperlunya.

Secara umum hasil dari pembinaan yang diharapkan oleh KESBANGPOL Kota Sungai Penuh adalah tidak terjadinya perselisihan, tidak adanya kasus yang menonjol tentang SARA, mantapnya persatuan, serta stabilnya kehidupan social politik di daerah. 


\section{Pembinaan terhadap organisasi kekuatan social politik}

Berdasarkan Undang Undang Republik Indonesia Nomor 2 Tahun 2008 Tentang Partai Politik, jumlah organisasi social politik yang terdaftar di KESBANGPOL Kota Sungai Penuh dapat dilihat pada tabel IV.

Tabel IV. Jumlah Partai Politik yang Terdaftar Tahun 2018

\begin{tabular}{cll}
\hline NO & \multicolumn{1}{c}{ NAMA PARTAI } & JUMLAH \\
\hline 1 & Partai Kesatuan Bangsa & 1 \\
\hline 2 & Partai GERINDRA & 1 \\
\hline 3 & Partai PDI Perjuangan & 1 \\
\hline 4 & Partai GOLKAR & 1 \\
\hline 5 & Partai Nasdem & 1 \\
\hline 6 & Partai Berkarya & 1 \\
\hline 7 & PKS & 1 \\
\hline 8 & Partai PERINDO & 1 \\
\hline 9 & PPP & 1 \\
\hline 10 & PAN & 1 \\
\hline 11 & Partai HANURA & 1 \\
\hline 12 & Partai Demokrat & 1 \\
\hline 13 & Partai Bulan Bintang & 1 \\
\hline 14 & PKP Indonesia & 14 \\
\hline
\end{tabular}

Sumber : Data Kesbangpol Kota Sungai Penuh

Melihat banyaknya organisasi kekuatan social politik yang ada, adapun pembinaan yang telah dilakukan adalah :

a. Pembinaan penyelenggaraan dalam pelaksanaan pemilihan umum.

Pada waktu menghadapi pemilihan umum tahun 2014 Di Kota Sungai Penuh, KESBANGPOL Kota Sungai Penuh melakukan pembinaan terhadap Organisasi peserta PEMILU. Adapun pembinaan yang dilakukan menurut Bapak Desveva Endri antara lain:

1. Melakukan pertemuan berskala dua kali setahun kepada pengurus partai peserta PEMILU.

2. Membantu memecahkan persoalan yang dihadapi organisasi tersebut dalam menghadapi pemilihan umum.

3. Membantu pengadaan fasilitas operasional seperti peralatan kantor, kendaraan dan dana.

Upaya-upaya yang dilakukan oleh jajaran KESBANGPOL Kota Sungai Penuh baik pembinaan terhadap organisasi kekuatan social politik maupuan pembinaan organisasi kemasyarakatan pada dasarnya juga merupakan upaya dalam menghadapi tantangan-tantangan pembangunan khususnya dalam bidang social politik. Mengingat 
peserta pemilihan umum itu adalah masyarakat maka KESBANGPOL Kota Sungai Penuh juga melakukan pembinaan terhadap masyarakat. Pembinaan yang dimaksud menurut Bapak Zarkasi adalah :

1. Memanfaatkan setiap pertemuan antara Pemerintah Daerah dan Masyarakat untuk mengajak seluruh warga negara Republik Indonesia yang telah mempunyai hak memilih untuk memberikan suaranya pada pemilihan umum.

2. Menghimbau masyarakat untuk turut menjaga keamanan dan ketertiban di lingkungannya agar pemilihan umum dapat berjalan dengan langsung, bebas dan rahasia.

3. Memberikan penyuluhan-penyuluhan melalui organisasi kemasyarakatan akan arti pentingnya pemilihan umum untuk pembangunan selanjutnya.

4. Memasang spanduk-spanduk, radio dan surat kabar yang berisikan himbauan kepada masyarakat untuk mensukseskan pemilihan umum.

Langkah-langkah yang ditempuh bertujuan untuk menimbulkan kesadaran masyarakat akan hak dan kewajibannya dalam kehidupan berpolitik, baik sebagai warga negara maupun masyarakat. Sehingga pemilihan umum dapat terlaksana sebgaimana yang diharapkan.

Disamping tugas-tugas tersebut diatas, KESBANGPOL Kota Sungai Penuh juga mempersiapkan segala sesuatu yang berkenaan dengan kelancaran pelaksanaan pemilihan umum yaitu secretariat panitia pemilihan, alat komunikasi, transfortasi dan perlengkapan lainnya.

Untuk mencapai efisiensi dari setiap kegiatan, terutama bagi personil penyelenggaran pemilihan umum maka perlu peningkatan pengetahuan dan keterampilan untuk itu diadakan berbagai kegiatan-kegiatan pembinaan terhadap panitia penyelenggara pemilihan umum.

Hasil dari pembinaan tersebut terbukti dengan suksesnya pemilihan umum pada tahun 2014 untuk Daerah Kota Sungai Penuh yang dapat dilihat dari tabel berikut :

Tabel V. Jumlah Pemilih di Kota Sungai Penuh pada Pemilihan Umum Tahun 2014

\begin{tabular}{|c|c|c|}
\hline No & Jenis Kelamin & Jumlah Suara \\
\hline 1 & Laki-laki & 31.331 \\
\hline 2 & Perempuan & 33.101 \\
\hline & JUMLAH & 64.432 \\
\hline
\end{tabular}

Sumber : Data KPU Kota Sungai Penuh 
Dari hasil pemilihan tersebut terdapat wakil-wakil rakyat dari organisasi peserta pemilihan umum untuk duduk pada Dewan Perwakilan Rakyat daerah Tingkat II Kota Sungai Penuh. Hal ini tergambar dari tabel berikut :

Tabel V. Jumlah Anggota Dewan Perwakilan Rakyat Daerah Tingkat II Kota Sungai Penuh berdasarkan hasil pemilihan umum Tahun 2014

\begin{tabular}{llc}
\hline No & Nama Partai & Jumlah Wakil \\
\hline 1 & Partai Demokrat & 5 \\
2 & PAN & 3 \\
3 & Partai HANURA & 3 \\
4 & PDI Perjuangan & 3 \\
5 & Partai GERINDRA & 3 \\
6 & Partai GOLKAR & 2 \\
7 & PPP & 2 \\
8 & PKS & 2 \\
9 & PKB & 1 \\
10 & Partai NASDEM & 1 \\
\hline & & 25 \\
\hline
\end{tabular}

Sumber : DPRD Kota Sungai Penuh

b. Pembinaan dengan lembaga pemerintah

Untuk merencanakan ataupun mengambil langkah-langkah dan kebijaksanaan lebih lanjut sesuai dengan tugas dan fungsinya KESBANGPOL Kota Sungai Penuh melakukan koordinasi dengan pimpinan daerah dan instansi terkait.

Kota Sungai Penuh minimal sekali dalam setahun melakukan rapat koordinasi dengan seluruh aparatur pemerintah baik dengan unsure pemerintah daerah maupun dengan instansi dinas dan jawatan secara terkoordinasikan perencanaan untuk tahun-tahun berikutnya.

Begitu pentingnya koordinasi maka kerjasama dan konsultasi dengan semua aparatur pemerintah sehingga terjalinnya ikatan aspiratif yang mengacu kepada tantangan persiapan dari KESBANGPOL LINMAS itu sendiri secara terarah dan terpadu. Diharapkan menjadi pusat dialog terutama dalam menampung aspirasi masyarakat yang menuntut pada kualitas politik.

Dengan adanya koordinasi ini Pemerintah Daerah mengajak masyarakat untuk ikut berpartisipasi aktif dalam pembangunan dimana baik pemerintah atau masyarakat samasama menjalankan fungsi dan peranan yang diemban sehingga proses infut-outfut dapat berlangsung sesuai dengan mekanisme demokrasi pancasila, selain itu juga dapat dilakukan pendidikan politik kepada masyarakat tentang semua kebijaksanaan pembangunan baik yang berskala nasional maupun daerah ini dapat dilakukan dengan keteladanan dengan pelaku-pelaku politik. 


\section{Kendala-kendala yang dihadapi dan Upaya Penanggulangannya}

Pembinaan dibidang social politik guna mewujudkan Demokrasi Pancasila yang semakin mantap terus dikembangkan. Sehubungan dengan pelaksanaan pembinaan tersebut masih banyak kendala-kendala yang ditemukan oleh KESBANGPOL Kota Sungai Penuh yaitu:

1. Masih banyaknya organisasi/LSM/Yayasan yang belum mendaftarkan keberadaannya pada KESBANGPOL LINMAS Kota Sungai Penuh.

2 Masih adanya organisasi kemasyarakatan/LSM/Yayasan yang belum atau tidak mengadakan konsolidasi kepengurusan organisasi baik kepengurusan maupun yang lainnya.

3. Masih adanya organisasi kemasyarakatan/LSM/Yayasan yang tidak aktif melaporkan kegiatannya baik secara berkala maupun insedentil.

4. Masih adanya organisasi kemasyarakatan /LSM/Yayasan yang belum mempunyai kantor secretariat tersendiri (berkantor di rumah pengurus/ketua) dan tidak memasang papan nama organisasi.

Untuk mengatasi kendala-kendala sebagaimana yang telah dikemukakan diatas,

KESBANGPOL LINMAS Kota Sungai Penuh mengambil langkah- langkah antara lain :

1. Terhadap organisasi kemasyarakatan yang belum mendaftarkan keberadaaannya, KESBANGPOL Kota Sungai Penuh menghimbau dan menyurati secara resmi organisasi tersebut agar mendaftarkan diri.

2. Bagi organisasi kemasyarakatan yang tidak mengadakan konsolidasi kepengurusan, tidak melaporkan kegiatannya, maupun yang tidak mempunyai kantor secretariat dan papan nama organisasi, KESBANGPOL Kota Sungai Penuh berusaha untuk memonitor pelaksanaan program organisasi dan melakukan pendekatan informal yang ada mengikuti peraturan perundang-undangan yang berlaku misalnya, mengadakan silaturahmi antar unsur pemerintah daerah dengan organisasi kemasyarakatan/LSM.

\section{PENUTUP}

Berdasarkan hasil pembahasan, maka diperoleh kesimpulan sebagai berikut :

1. Usaha-usaha yang dilakukan oleh KESBANGPOL LINMAS Kota Sungai Penuh untuk menjaga kestabilan politik dibidang social politik adalah dengan melakukan pembinaan terhadap organisasi kemasyarakatan yang ada, pembinaan tersebut dilakukan lewat pelatihan-pelatihan dibidang social politik. Sedangkan terhadap organisasi kekuatan social 
politik dilakukan pembinaan dibidang penyelenggaraan dalam pelaksanaan pemilihan umum dengan cara melakukan pertemuan berskala dua kali setahun kepada pengurus organisasi social politik,membantu memecahkan persoalan yang dihadapi organisasi tersebut dalam menghadapi pemilihan umumdan membantu mengadakan fasilitas operasional.

2 Kendala-kendala yang dihadapi

a. Masih banyaknya organisasi/LSM/Yayasan yang belum mendaftarkan keberadaannya pada KESBANGPOL LINMAS Kota Sungai Penuh.

b. Masih adanya organisasi kemasyarakatan/LSM/Yayasan yang belum atau tidak mengadakan konsolidasi kepengurusan organisasi baik kepengurusan maupun yang lainnya.

c. Masih adanya organisasi kemasyarakatan/LSM/Yayasan yang tidak aktif melaporkan kegiatannya baik secara berkala maupun insedentil.

d. Masih adanya organisasi kemasyarakatan /LSM/Yayasan yang belum mempunyai kantor secretariat tersendiri (berkantor di rumah pengurus/ketua) dan tidak memasang papan nama organisasi.

Untuk mengatasi kendala-kendala sebagaimana yang telah dikemukakan diatas, KESBANGPOL Kota Sungai Penuh mengambil langkah-langkah antara lain :

1. Terhadap organisasi kemasyarakatan yang belum mendaftarkan keberadaaannya, KESBANGPOL LINMAS Kota Sungai Penuh menghimbau dan menyurati secara resmi organisasi tersebut agar mendaftarkan diri.

2. Bagi organisasi kemasyarakatan yang tidak mengadakan konsolidasi kepengurusan, tidak melaporkan kegiatannya, maupun yang tidak mempunyai kantor secretariat dan papan nama organisasi, KESBANGPOL LINMAS Kota Sungai Penuh berusaha untuk memonitor pelaksanaan program organisasi dan melakukan pendekatan informal yang ada mengikuti peraturan perundang- undangan yang berlaku misalnya, mengadakan silaturahmi antar unsur pemerintah daerah dengan organisasi kemasyarakatan/LSM.

\section{REFERENSI}

Andi Yusran, Ilmu Politik: Paradigma, Makna dan Konsep Sistem, Pekanbaru: Suska Press \& Red-PoSt Press, 2007

Agus Dwiyanto, 2008, Mewujudkan Good Governance Melalui Pelayanan Publik, Gadjah Mada, Yogyakarta: University Press. 
Agung Kurniawan, 2005, Transformasi Pelayanan Publik, Yogyakarta: Pembaruan.

Budi Supriyanto, 2009, Manajemen Pemerintahan (Plus Dua Belas Langkah Strategis), CV. Media Brilian, Tangerang.

C.S.T. Kansil dan Christine S.T. Kansil, Sistem Pemerintahan Indonesia, Jakarta: Bumi Aksara.

J.S. Badudu dan Sutan Mohammad Zain, 2001, Kamus Umum Bahasa Indonesia, Jakarta: Sinar Harapan.

Lexy Moeleong, 2002, Metodologi Penelitian Kualitatif, Bandung: Remaja Rosda Karya.

Lijan Poltak Sinambela, dkk., 2008, Reformasi Pelayanan Publik : Teori, Kebijakan dan Empiris, Jakarta: Bumi Aksara.

Miriam Budiardjo, Dasar-Dasar Ilmu Politik, Jakarta: Gramedia Pustaka Utama, 2008.

Mochtar Mas'oed dan Colon MacAndrews, Perbandingan Sistem Politik, Yogyakarta: Gadjah Mada University Press, 2001.

Muhammad Labolo, 2010, Memahami Ilmu Pemerintahan, Raja Grafindo Perkasa, Jakarta.

Rahardjo Adisasmita, 2011. Manajemen Pemerintahan Daerah, Graha Ilmu, Yogyakarta.

Sampara Lukman, 2000, Manajemen Kualitas Pelayanan, Jakarta: STIA LAN Press.

Taliziduhu Ndraha, 1997, Metodologi Ilmu Pemerintahan, Jakarta: Rineka Cipta.

Zamroni, 2011, Pendidikan Demokrasi pada Masyarakat Multikultural, Gavin Kalam Utama, Jakarta. 